\title{
The relationship between reference canopy conductance and simplified hydraulic architecture
}

\author{
Kimberly Novick $^{\mathrm{a}, *}$, Ram Oren ${ }^{\mathrm{a}}$, Paul Stoy ${ }^{\mathrm{b}}$, Jehn-Yih Juang ${ }^{\mathrm{c}}$, Mario Siqueira ${ }^{\mathrm{a}, \mathrm{d}}$, Gabriel Katul ${ }^{\mathrm{a}}$ \\ a Nicholas School of the Environment, Duke University, Box 90328, Durham, NC 27708, USA \\ ${ }^{\mathrm{b}}$ Department of Atmospheric and Environmental Science, School of GeoSciences, University of Edinburgh, Edinburgh EH9 3JN, UK \\ ${ }^{\mathrm{C}}$ Department of Geography, National Taiwan University, Taipei, Taiwan \\ ${ }^{\mathrm{d}}$ Departamento de Engenharia Mecanica, Universidade de Brasília, Brazil
}

\section{A R T I C L E I N F O}

Article history:

Received 19 May 2008

Received in revised form 8 December 2008 Accepted 5 February 2009

Available online 20 February 2009

\section{Keywords:}

Canopy conductance

Canopy height

Evapotranspiration

Leaf area

Leaf-to-sapwood area ratio

Sapwood area

Sap flux

Transpiration

\begin{abstract}
A B S T R A C T
Terrestrial ecosystems are dominated by vascular plants that form a mosaic of hydraulic conduits to water movement from the soil to the atmosphere. Together with canopy leaf area, canopy stomatal conductance regulates plant water use and thereby photosynthesis and growth. Although stomatal conductance is coordinated with plant hydraulic conductance, governing relationships across species has not yet been formulated at a practical level that can be employed in large-scale models. Here, combinations of published conductance measurements obtained with several methodologies across boreal to tropical climates were used to explore relationships between canopy conductance rates and hydraulic constraints. A parsimonious hydraulic model requiring sapwood-to-leaf area ratio and canopy height generated acceptable agreement with measurements across a range of biomes $\left(r^{2}=0.75\right)$. The results suggest that, at long time scales, the functional convergence among ecosystems in the relationship between water-use and hydraulic architecture eclipses inter-specific variation in physiology and anatomy of the transport system. Prognostic applicability of this model requires independent knowledge of sapwood-to-leaf area. In this study, we did not find a strong relationship between sapwood-to-leaf area and physical or climatic variables that are readily determinable at coarse scales, though the results suggest that climate may have a mediating influence on the relationship between sapwood-to-leaf area and height. Within temperate forests, canopy height alone explained a large amount of the variance in reference canopy conductance $\left(r^{2}=0.68\right)$ and this relationship may be more immediately applicable in the terrestrial ecosystem models.
\end{abstract}

(c) 2009 Elsevier Ltd. All rights reserved.

\section{Introduction}

Canopy stomatal conductance to water vapor $\left(G_{S}\right)$ is a primary determinant of ecosystem transpiration rates. Over the past few decades, much attention has been focused on describing the response of $G_{s}$ to the variables that act on fast time scales (e.g. hourly). In comparison, little attention has been paid to processes that may impact canopy conductance on longer time scales (e.g. yearly). Generic relationships that are valid across species have been developed for the fast responses of $G_{s}$ to photosynthetically active radiation $(P A R,[1])$, vapor pressure deficit $(D,[2])$, and soil moisture content $(\theta,[1])$ and have been implemented in large-scale models. These models typically rely on a reference canopy conductance rate $\left(G_{\text {sref }}\right)$, defined at a specific environmental state that can vary across applications and adjusted for the fast-acting meteoro-

\footnotetext{
* Corresponding author. Tel.: +1 9194344224.

E-mail addresses: kan2@duke.edu (K. Novick), ramoren@duke.edu (R. Oren), stoy@staffmail.ed.ac.uk (P. Stoy), jjuang@ntu.edu.tw (J.-Y. Juang), mbs4@duke.edu (M. Siqueira), gaby@duke.edu (G. Katul).
}

logical variables. These adjustments can be based on multiplicative functions that take a range of mathematical forms (hereafter referred to as $f_{1}(V P D), f_{2}(P A R)$, and $f_{3}(\theta)$ ). One such formulation is the widely used "Jarvis-type" model which can be expressed as [3]:

$G_{s}=G_{\text {sref }} \cdot f_{1}(V P D) \cdot f_{2}(P A R) \cdot f_{3}(\theta)$.

$G_{\text {sref }}$ significantly varies across stands of different age, structure and vegetation type, and changes predictably with measurable features of canopy structure, at least within a species [4-6]. However, the current suite of the terrestrial ecosystem models do not account for mechanisms that impact $G_{\text {sref }}$ over longer time scales. Some dynamic global vegetation models (DGVMs) and stand-level models assume that the canopy stomatal conductance parameters are 'static' for a range of canopy architectural scenarios, while others change the parameters empirically with stand age, or require species-specific allometric relationships that are difficult to implement over large and biologically diverse land areas [7,8]. Traditionally, these assumptions were necessary given the lack of spatial datasets of elementary hydraulic parameters known to impact $G_{s}$. Recent 
advances in LIght Detection and Ranging (LIDAR) imaging technology now facilitate detailed mapping of key properties of canopy architecture for large land areas [9,10], and elevation datasets from the Shuttle Radar Topography Mission (SRTM) appear capable of producing maps of canopy height $(h)$ over most of the global land surface [11].

Mechanistic relationships between the parameters controlling $G_{s}$ and remotely sensed features of canopy architecture (such as $h$ ), if present, could improve biosphere-atmosphere mass and energy exchange estimates at large spatial scales. To our knowledge, no attempt has been made to determine whether such generic relationships exist between measurable features of hydraulic architecture and canopy conductance among diverse species at the level of simplicity that permits incorporation into coarse-scale models. On the other hand, relationships between canopy conductance and features of canopy architecture have been well documented within species. A predictable decrease in both leaf-level and mean canopy stomatal conductance with canopy height has been reported for a range of species, including Fagus sylvatica [4], Picea abies [12], Pinus palustris [13], Pinus pinaster [5], Pinus ponderosa [14], Pinus taeda [15], and Quercus garryana [16]. In many cases, this decrease is attributed to an increased hydraulic resistance associated with an increased path length. However, several of these studies also suggest that sapwood-to-leaf area ratio $\left(A_{S} / A_{L}\right)$ is another important determinant of $G_{s}[4,17,18,5]$, and in some cases alterations in $A_{S} / A_{L}$ can nearly compensate for height or physiologically based reductions in $G_{s}$ [19]. It is therefore likely that the most parsimonious generic model of canopy conductance accounting for readily measurable features of hydraulic architecture must consider, at minimum, $A_{S} / A_{L}$ and $h$. This investigation was made to assess the performance of such a model over a wide range of climatic regimes and species.

\section{Theoretical considerations and hypotheses}

\subsection{Relating transpiration and conductance to hydraulic architecture}

The cohesion-tension theory for water transport in trees [20] has been used to explain the contribution of hydraulic characteristics to variations in $G_{s}$. Within species, theoretical relationships between canopy stomatal conductance and canopy architecture are often derived by equating the soil-to-leaf water flux to the leaf-level transpiration rate $\left(T_{r}, \mathrm{mmol} \mathrm{m}^{-2} \mathrm{~s}^{-1}\right)$ under steady-state flow conditions [21,22], yielding:

$T_{r}=K\left(\Psi_{\text {soil }}-\Psi_{\text {leaf }}-\rho_{w} g h\right)$,

where $K\left(\mathrm{mmol} \mathrm{m}^{-2} \mathrm{~s}^{-1} \mathrm{MPa}^{-1}\right)$ is the leaf-level hydraulic conductivity from the soil to the leaf, $g$ is the gravitational acceleration $\left(\mathrm{m} \mathrm{s}^{-2}\right), \rho_{w}$ is the density of water $\left(\mathrm{kg} \mathrm{cm}^{-3}\right)$, and $\Psi_{\text {soil }}-\Psi_{\text {leaf }}$ (MPa) is the soil-to-leaf pressure difference. Noting that $K$ is proportional to the sapwood area and inversely proportional to soil-to-leaf path length $[2,4]$ yields:

$T_{r}=k_{s} \frac{A_{S}}{A_{L} h}\left(\Psi_{\text {soil }}-\Psi_{\text {leaf }}-\rho_{w} g h\right)$,

where the path length from $\Psi_{\text {soil }}$ to $\Psi_{\text {leaf }}$ is approximated by $h$, and $k_{s}$ is the tissue-specific hydraulic conductivity per unit sapwood area $\left(\mathrm{mmol} \mathrm{m}^{-1} \mathrm{~s}^{-1} \mathrm{MPa}^{-1}\right)$.

Ecosystem- and coarse-scale carbon cycling models often assume that, at long time scales, leaf boundary layer conductance has negligible influence on total canopy conductance. With this assumption, the stomatal response to changes in hydraulic architecture can be predicted by substituting $G_{s}$ and the vapor pressure deficit $(D, \mathrm{MPa})$ for the transpiration rate in Eq. (3) $[3,23,24,13]$, yielding:
$G_{s} D=k_{s} \frac{A_{S}}{A_{L} h}\left(\Psi_{\text {soil }}-\Psi_{\text {leaf }}-\rho_{w} g h\right)$.

\subsection{Separating fast and slow responses}

As noted earlier, $G_{S}$ responds rapidly to the changes in PAR, $D$, and $\theta$ via the multiplicative functions $f_{1}(V P D), f_{2}(P A R)$, and $f_{3}(\theta)$. Therefore, to isolate the effects of $A_{S} / A_{L}, k_{s}, \Psi_{\text {leaf }}$, and $h$ on $G_{s}$ from the effects of rapidly changing variables, a conductance rate at a reference environmental state $\left(G_{\text {sref }}\right)$ is used. In this analysis, the reference environmental state is characterized by non-limiting light and soil moisture (i.e. $f_{2}(P A R)=f_{3}(\theta)=1$ ), and a reference $V P D$ of $1 \mathrm{kPa}$. Estimates of $G_{\text {sref }}$ may be adjusted to reflect varying environmental conditions to produce a continuous estimate of $G_{\text {sref }}$ as per Eq. (1) with multiplicative functions, if they are known. In the case of inter-specific application of the Jarvis model, at least one variant of the three functions $f_{1}(V P D), f_{2}(P A R)$, and $f_{3}(\theta)$ had already been formulated (see Oren et al. [2] for $f(V P D)$, and Granier et al. [1] for $f(P A R)$ and $f(\theta)$ ).

When only non-limiting soil moisture states are considered (as specified by the reference environmental state), $\left|\Psi_{\text {soil }}\right|$ is typically an order of magnitude less than $\left|\Psi_{\text {leaf }}\right|$. Therefore, we neglect $\left|\Psi_{\text {soil }}\right|$ in Eq. (4) relative to $\left|\Psi_{\text {leaf }}\right|$, noting that this may introduce a bias on the order of $10-20 \%$ in plants with relatively low $\left|\Psi_{\text {leaf }}\right|$ (Fig. 1). With this assumption, $G_{\text {sref }}$ can be expressed as a function of $A_{S} / A_{L}, k_{s}, \Psi_{\text {leaf }}$, and $h$ using:

$G_{\text {sref }}=k_{s} \frac{A_{s}}{A_{L} h}\left(\Psi_{\text {leaf }}-\rho_{w} g h\right)$.

This formulation assumes that canopy height is a proxy for the mean path length from the soil through the rooting zone to the leaf. Conditions in which $h$ does not represent this path length for water flow are likely to occur in two types of ecosystems: (a) canopies with deep rooting relative to the total path length (i.e., mature short stature forests), and (b) canopies where complicated vertical branch architecture patterns make $h$ a poor proxy for the mean path length. In the former scenario, a rooting length of $1 \mathrm{~m}$ results in a $5 \%$ error in $k_{s} \frac{A_{s}}{A_{h} h}$ for a $10 \mathrm{~m}$ canopy (Fig. 1). Similarly, a rooting length of 2 and $3 \mathrm{~m}$ results in errors of ca. $15 \%$ and $20 \%$, respectively. In the case of taller canopies, the error introduced by equating $h$ with the path length decreases with increasing $h$.

To assess the relative contribution of each of these four variables to inter-specific variation in the reference conductance rates, the observed natural variation in these parameters is considered first. In general, $\Psi_{\text {leaf }}$ is typically around $-2 \mathrm{MPa}[5,25,26]$, although values as high as $\Psi_{\text {leaf }}=-1.0 \mathrm{MPa}$ (Picea mariana, [27]) and $\Psi_{\text {leaf }}=-1.1 \mathrm{MPa}$ (Eucalyptus saligna, [19]), and as low as $\Psi_{\text {leaf }}=-3.28 \mathrm{MPa}$ (tropical species, [28]) and even much lower have been reported. The hydraulic conductivity, $k_{s}$, varies across species by about an order of magnitude, from $<30 \mathrm{mmol} \mathrm{m}^{-1} \mathrm{~s}^{-1} \mathrm{MPa}^{-1}$ for gymnosperms to $>130$ mmol m${ }^{-1} \mathrm{~s}^{-1} \mathrm{MPa}^{-1}$ for some evergreen angiosperms [29].

Variations in $A_{S} / A_{L}$ across species are comparable to variations in $k_{s}$, ranging from values as low as $0.7 \mathrm{~cm}^{2} \mathrm{~m}^{-2}$ for tropical E. saligna [19] and $0.5 \mathrm{~cm}^{2} \mathrm{~m}^{-2}$ for boreal species [27] to ratios as high as $13 \mathrm{~cm}^{2} \mathrm{~m}^{-2}$ for $P$. palustris [13] and $14 \mathrm{~cm}^{2} \mathrm{~m}^{-2}$ for Taxodium distichum [30]. Even greater variations are found over the landscape in $h$, which can range from less than a meter to over $100 \mathrm{~m}$.

Therefore, if independence is assumed among all the driving variables in Eq. (5), we expect that both the products $k_{S}\left(\Psi_{\text {leaf }}-\rho_{w} g h\right)$ and $A_{S} / A_{L} / h$ vary by approximately an order of magnitude across species, and each group of variables could explain roughly $50 \%$ of the interspecies variation in $G_{s r e f}$ if all other 


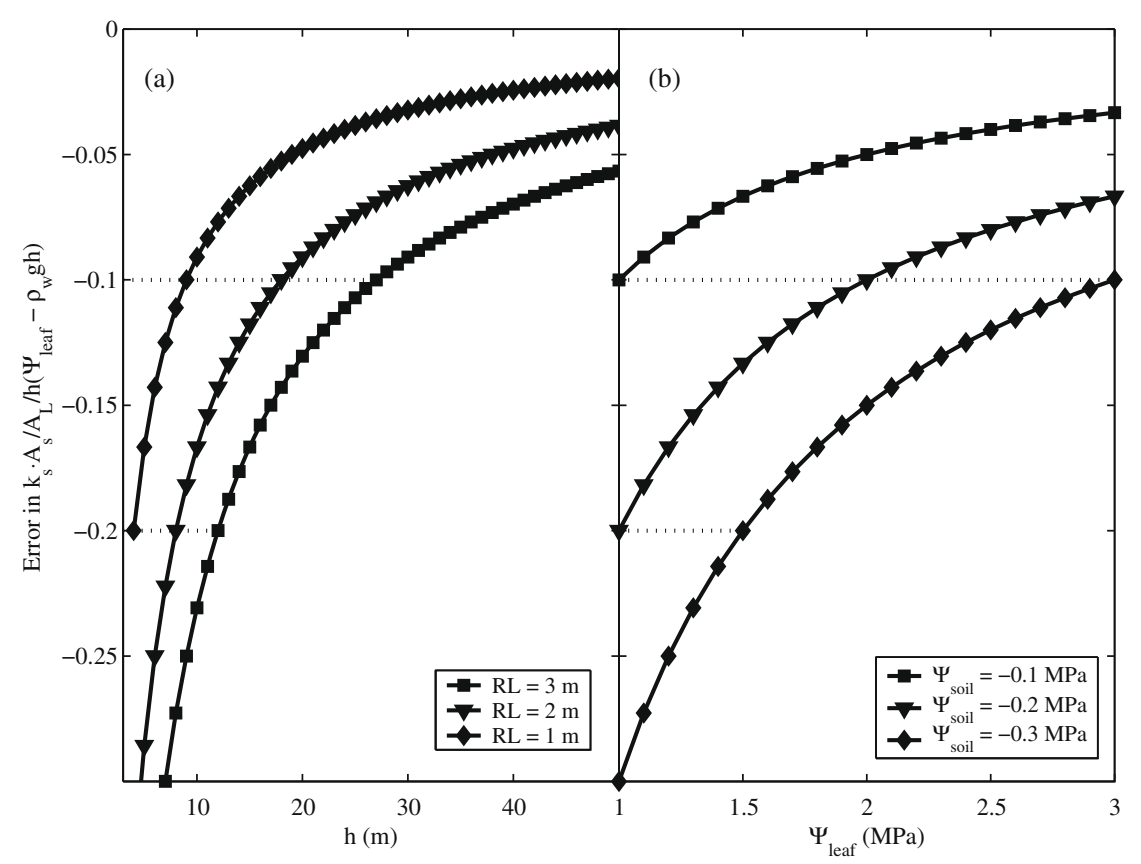

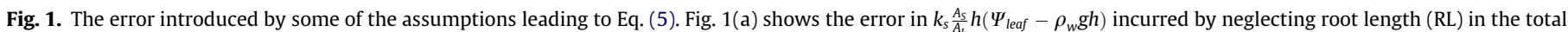

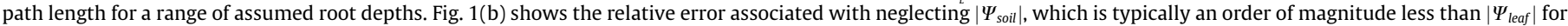
a range of soil water potentials. The dotted lines indicate $10 \%$ and $20 \%$ errors.

assumptions in the model are valid. In actuality, some coordination among these variables is likely. For example, within species, $A_{S} / A_{L}$ and $h$ are often tightly correlated $[4,31,27]$ and are linked by a simple linear relationship:

$\frac{A_{S}}{A_{L}}=\alpha h+\beta$.

However, $\alpha$ can be either positive or negative [31], and can vary from as low as $-0.41 \mathrm{~cm}^{2} \mathrm{~m}^{-3}$ (P. mariana, [27]) to as high as $0.21 \mathrm{~cm}^{2} \mathrm{~m}^{-3}$ (Pinus sylvestris, [32]). Hence, across species, $A_{S} / A_{L}$ and $h$ are expected to be less correlated than among stands of the same species. Furthermore, compensating relationships between $\Psi_{\text {leaf }}$ and $k_{s}$ should be considered. Trees growing in dry environments conducive to producing low (i.e., more negative) $\Psi_{\text {leaf }}$ produce tissues with lower xylem vulnerability to cavitation accompanied by lower $k_{s}[33,24]$. Conversely, plants producing tissues with high $k_{s}$ must maintain higher $\Psi_{\text {leaf }}$ to prevent xylem cavitation [34]. Thus, a change in $\Psi_{\text {leaf }}$ that could have a positive effect on $G_{\text {sref }}$ would probably be accompanied by an opposing change in $k_{s}$ and vice versa. We note, however, than a recent review article failed to find a strongly significant relationship between $\Psi_{\text {leaf }}$ and $k_{s}$ across species [35].

In this article, we focus on the relationship between $G_{\text {sref }}$ and $A_{S} / A_{L} / h$ as canopy height is an easily measurable feature of canopy architecture, and sapwood-to-leaf area is far simpler to measure at the stand-scale than $G_{\text {sref }}$. Furthermore, $A_{S} / A_{L}$ may be determined $a$ priori for some species based on established allometric relationships or LIDAR remote sensing. We hypothesize that, hydraulically, $A_{S} / A_{L}$ and $h$ should exert a strong control over $G_{\text {sref }}$, explaining approximately $50 \%$ of the variation in reference conductance via:

$G_{\text {sref }} \propto \frac{A_{S}}{A_{L} h}$.

Within this framework, results from two literature surveys are used to examine whether general relationships between $G_{\text {sref }}, h$, and $A_{S} / A_{L}$ emerge which are sufficiently strong to eclipse inter-specific variation in $\Psi_{\text {leaf }}$ and $k_{s}$.

\section{Methods}

Two independent literature surveys were conducted. The first survey was designed to explore inter-specific variation between $G_{\text {sref }}, h$, and $A_{S} / A_{L}$. The second survey was used to determine the extent of inter-specific variability in $\alpha$ (and hence, $A_{S} / A_{L}$ ), and to evaluate whether such variations can be related to climate controls, phylogenetic similarity, or other ecosystem features.

\subsection{Survey 1 - Relationships between $G_{\text {sref }}, h$, and $A_{S} / A_{L}$}

Published estimates of $h$ and $G_{\text {sref }}$ were obtained and analyzed for 42 closed-canopy forest ecosystems representing a wide range of species from boreal to tropical climates (Survey 1, Table 1). Estimates of $A_{S} / A_{L}$ were available for 29 of these sites. These studies relied on canopy transpiration obtained by either sap-flux or eddy covariance methodologies, averaged over a range of time scales from half-hourly to daily. Typically, canopy conductance was derived in these studies from the estimates of transpiration and $D$ using [36]:

$G_{s}=\frac{K_{u}(T) \cdot T_{r}}{D \cdot A_{L}}$

where $K_{u}(T)$ is a temperature-dependent constant derived from the latent heat of vaporization, the specific heat capacity of dry air, mean air density, and the psychrometric constant, and $A_{L}$ is, as before, the leaf area. In the case of the six eddy-covariance estimates, measures were taken at each site to ensure that conductance was derived from measured water vapor fluxes that did not include a significant contribution from soil evaporation. In the case of the Populus tremuloides and Pinus radiata canopies, soil evaporation was measured independent of whole-canopy evaporation using lysimeters. In the $P$. mariana stand, soil and sub-canopy evapotranspiration were measured with a below-canopy eddy-covariance system. In the $6.8 \mathrm{~m}$ P. taeda stand, $G_{s}$ estimated from whole-canopy evapotranspiration fluxes and from sap-flux data responded 
Table 1

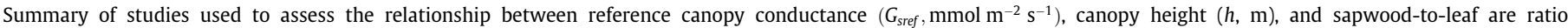

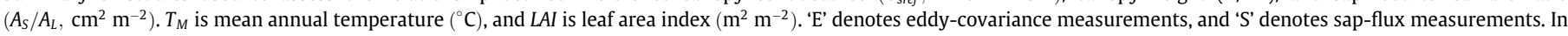

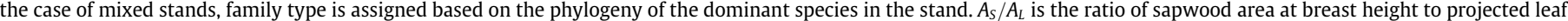
area unless otherwise noted.

\begin{tabular}{|c|c|c|c|c|c|c|c|c|c|}
\hline Dominant species & Location & Family & $T_{M}$ & $h$ & $G_{\text {sref }}$ & $L A I$ & $A_{S} / A_{L}$ & Method & Reference \\
\hline \multicolumn{10}{|l|}{ Boreal Forests } \\
\hline Picea abies & $64.12 \mathrm{~N}, 19.27 \mathrm{E}$ & Pinaceae & 2 & 9.7 & 49 & 6.0 & 4.9 & $\mathrm{~S}$ & [58] \\
\hline Picea abies & $60.08 \mathrm{~N}, 17.48 \mathrm{E}$ & Pinaceae & 5.5 & 23 & 180 & 4.5 & & $\mathrm{~S}$ & [61] \\
\hline Populus temuloides & $53.63 \mathrm{~N}, 106.20 \mathrm{~W}$ & Salicaceae & 0.4 & 22 & 134 & 3.3 & 11.3 & $\mathrm{E}$ & [59] \\
\hline Picea mariana & $55.88 \mathrm{~N}, 90.30 \mathrm{~W}$ & Pinaceae & 0.8 & 9 & 55 & 7.5 & $2.5^{\mathrm{a}}$ & $\mathrm{S}$ & [27] \\
\hline Picea mariana & $55.88 \mathrm{~N}, 90.30 \mathrm{~W}$ & Pinaceae & 0.8 & 10 & 42 & 6.1 & $2.1^{\mathrm{a}}$ & $\mathrm{S}$ & [27] \\
\hline Picea mariana & $55.88 \mathrm{~N}, 98.48 \mathrm{~W}$ & Pinaceae & -3.2 & 12 & 35 & 4.6 & $2.2^{\mathrm{b}}$ & $\mathrm{E}$ & [60] \\
\hline Pinus sylvestris & $60.72 \mathrm{~N}, 89.13 \mathrm{E}$ & Pinaceae & 5.5 & 17.4 & 82 & 5.0 & 7.1 & $\mathrm{~S}$ & [62] \\
\hline Pinus sylvestris & $60.08 \mathrm{~N}, 17.48 \mathrm{E}$ & Pinaceae & 5.5 & 26.8 & 33 & 4.5 & 10.1 & $\mathrm{~S}$ & [62] \\
\hline \multicolumn{10}{|l|}{ Temperate Forests } \\
\hline Abies bornmulleriana & $48.73 \mathrm{~N}, 6.23 \mathrm{E}$ & Pinaceae & 9.6 & 11 & 75 & 8.9 & & $\mathrm{~S}$ & [1] \\
\hline Crataegus monogyna & $51.6 \mathrm{~N}, 1.7 \mathrm{~W}$ & Rosaceae & 9.5 & 4 & 241 & 4.8 & $8.8^{c}$ & $\mathrm{~S}$ & [44] \\
\hline Cryptomeria japonica D. & $33.13 \mathrm{~N}, 130.72 \mathrm{E}$ & Cupressaceae & 15 & 22 & 29 & 5.4 & 6.7 & $\mathrm{~S}$ & [63] \\
\hline Cryptomeria japonica D. & $33.13 \mathrm{~N}, 130.72 \mathrm{E}$ & Cupressaceae & 15 & 32 & 39 & 5.7 & 8.1 & $\mathrm{~S}$ & [63] \\
\hline Fagus sylvatica & $48.2 \mathrm{~N}, 7.25 \mathrm{E}$ & Fagaceae & 9.8 & 22.5 & 75 & 5.7 & & $\mathrm{~S}$ & [1] \\
\hline Fagus sylvatica & $48.67 \mathrm{~N}, 7.08 \mathrm{E}$ & Fagaceae & 9.2 & 14 & 87 & 5.7 & & $\mathrm{~S}$ & [1] \\
\hline Fagus sylvatica & $49.87 \mathrm{~N}, 10.45 \mathrm{~W}$ & Fagaceae & 6 & 23 & 83 & 6.2 & 3.9 & $\mathrm{~S}$ & {$[4]$} \\
\hline Mixed deciduous & $33.93 \mathrm{~N}, 79.13 \mathrm{~W}$ & Juglandaceae & 15.5 & 23 & 67 & 5.5 & 5.4 & $\mathrm{~S}$ & [64] \\
\hline Mixed deciduous & $46.24 \mathrm{~N}, 89.35 \mathrm{~W}$ & Aceraceae & 3.9 & 22 & 32 & 7.5 & 2.6 & $\mathrm{~S}$ & [65] \\
\hline Mixed deciduous & $33.93 \mathrm{~N}, 79.13 \mathrm{~W}$ & Juglandaceae & 15.5 & 25 & 93 & 6.1 & 5.4 & $\mathrm{E}$ & [37] \\
\hline Mixed deciduous & $51.79 \mathrm{~N}, 1.3 \mathrm{~W}$ & Aceraceae & 9.7 & 21 & 109 & 3.6 & & $\mathrm{~S}$ & [66] \\
\hline Mixed deciduous & $51.45 \mathrm{~N}, 1.27 \mathrm{~W}$ & Fagaceae & 10.9 & 22 & 82 & 3.9 & & $\mathrm{~S}$ & [66] \\
\hline Quercus alba & $35.87 \mathrm{~N}, 80.00 \mathrm{~W}$ & Fagaceae & 15.5 & 25 & 40 & 3.1 & 1.1 & $\mathrm{~S}$ & [67] \\
\hline Picea abies & $48.73 \mathrm{~N}, 6.23 \mathrm{E}$ & Pinaceae & 9.6 & 11 & 66 & 9.5 & & $\mathrm{~S}$ & [1] \\
\hline Picea abies & $48.2 \mathrm{~N}, 7.25 \mathrm{E}$ & Pinaceae & 6 & 13 & 93 & 6.1 & & $\mathrm{~S}$ & [1] \\
\hline Picea abies & $50.15 \mathrm{~N}, 11.87 \mathrm{E}$ & Pinaceae & 5.8 & 16.1 & 66 & 5.3 & 3.8 & $\mathrm{~S}$ & [49] \\
\hline Picea abies & $50.15 \mathrm{~N}, 11.87 \mathrm{E}$ & Pinaceae & 5.8 & 14.7 & 84 & 6.4 & 3.6 & $\mathrm{~S}$ & [49] \\
\hline Picea abies & $50.15 \mathrm{~N}, 11.87 \mathrm{E}$ & Pinaceae & 5.8 & 17.8 & 62 & 7.1 & 3.7 & $\mathrm{~S}$ & [49] \\
\hline Picea abies & $50.15 \mathrm{~N}, 11.87 \mathrm{E}$ & Pinaceae & 5.8 & 24.1 & 44 & 7.9 & 2.6 & $\mathrm{~S}$ & [49] \\
\hline Picea abies & $50.15 \mathrm{~N}, 11.87 \mathrm{E}$ & Pinaceae & 5.8 & 25.7 & 56 & 7.6 & 2.4 & $\mathrm{~S}$ & [49] \\
\hline Picea abies & $50.15 \mathrm{~N}, 11.87 \mathrm{E}$ & Pinaceae & 5.8 & 25.2 & 31 & 6.5 & 2.1 & $\mathrm{~S}$ & [49] \\
\hline Pinus pinaster & $44.70 \mathrm{~N}, 0.77 \mathrm{~W}$ & Pinaceae & 9.8 & 12 & 104 & 4.4 & 8.4 & $\mathrm{~S}$ & [68] \\
\hline Pinus pinaster & $44.08 \mathrm{~N}, 0.08 \mathrm{~W}$ & Pinaceae & 12.5 & 18 & 87 & 12.5 & 5.7 & $\mathrm{~S}$ & {$[68,69]$} \\
\hline Pinus taeda & $34.80 \mathrm{~N}, 72.20 \mathrm{~W}$ & Pinaceae & 15.5 & 6.8 & 154 & 3.5 & 6.8 & $\mathrm{E}$ & {$[15,70]$} \\
\hline Pinus taeda & $33.93 \mathrm{~N}, 79.13 \mathrm{~W}$ & Pinaceae & 15.5 & 16 & 113 & 4.5 & 8.2 & $\mathrm{E}$ & [37] \\
\hline Pinus radiata & $42.87 \mathrm{~S}, 172.75 \mathrm{E}$ & Pinaceae & 10.8 & 8 & 75 & 6.5 & & $\mathrm{E}$ & [71] \\
\hline Populus trichocarpa & $46.17 \mathrm{~N}, 118.47 \mathrm{~W}$ & Salicaceae & 12.3 & 8 & 148 & 9.5 & 3.3 & $\mathrm{~S}$ & [72] \\
\hline Quercus petraea & $48.7 \mathrm{~N}, 6.4 \mathrm{E}$ & Fagaceae & 9.6 & 15 & 95 & 6.0 & & $S$ & [1] \\
\hline \multicolumn{10}{|l|}{ Tropical Forests } \\
\hline Eperua falcata & $5.2 \mathrm{~N}, 52.7 \mathrm{~W}$ & Fabaceae & 25.8 & 10 & 43 & 10.8 & & $\mathrm{~S}$ & [1] \\
\hline Eucalyptus saligna & $19.84 \mathrm{~N}, 155.12 \mathrm{~W}$ & Myrtaceae & 21 & 7 & 40 & 4.9 & 0.7 & $\mathrm{~S}$ & [19] \\
\hline Eucalyptus saligna & $19.84 \mathrm{~N}, 155.12 \mathrm{~W}$ & Myrtaceae & 21 & 26 & 37 & 5.1 & 1.8 & $\mathrm{~S}$ & [19] \\
\hline Goupia glabra & $5.2 \mathrm{~N}, 52.7 \mathrm{~W}$ & Goupiaceae & 25.8 & 15 & 74 & 4.3 & & $\mathrm{~S}$ & [1] \\
\hline Mixed tropical & $5.2 \mathrm{~N}, 52.7 \mathrm{~W}$ & Fabaceae & 25.9 & 33 & 57 & 8.6 & 1.5 & $\mathrm{~S}$ & [1] \\
\hline Simarouba amara & $5.2 \mathrm{~N}, 52.7 \mathrm{~W}$ & Simaroubaceae & 25.8 & 4.7 & 108 & 3.5 & & $\mathrm{~S}$ & [1] \\
\hline
\end{tabular}

a These values are the ratio of sapwood area to total leaf area.

b Derived from tree-averaged sapwood area.

c Derived from sapwood area measurements taken at a height of $15 \mathrm{~cm}$.

similarly to $D$, suggesting that the eddy-covariance evapotranspiration fluxes in this canopy were driven primarily by transpiration. And finally, transpiration in the $16 \mathrm{~m} \mathrm{P}$. taeda stand and the mixed deciduous forest was partitioned from the measured evapotranspiration fluxes using a simple radiation transfer model as described in Stoy et al. [37].

For sites with high leaf area, it is well known that not all the foliage contributes to transpiration. Because total conductance rates are normalized by the measured $L A I$ to obtain $G_{s}$ rather than the $L A I$ contributing to stand transpiration, an adjustment is necessary for sites with high $L A I$. The $L A I$ (and hence the reference conductance rates) was corrected for sites with exceptionally high (i.e. $L A I \geqslant 8$ ) by multiplying by a factor $f=L A I / 8$. This correction is similar to that suggested by Granier et al. [1] though we choose to implement the correction only for sites with $L A I \geqslant 8$ (as opposed to $L A I \geqslant 6$ ) because this is roughly the value of $L A I$ at which the fraction of absorbed radiation in the canopy reaches $95 \%$ during midday hours when it is modeled from Beer's Law [38].
The reported values of $G_{\text {sref }}$ obtained from the literature were estimated using a range of analytical procedures, including boundary line analyses, optimization routines, and data binning. In all cases, the extracted value represents the authors' estimate of the conductance rate at the reference $D$ of $1 \mathrm{kPa}$ under the conditions of non-limiting light and soil moisture content. In this analysis, $G_{\text {sref }}$ is expressed in $\mathrm{mmol} \mathrm{m} \mathrm{m}^{-2} \mathrm{~s}^{-1}$. Reference conductance measurements presented in units of $\mathrm{mm} \mathrm{s}^{-1}$ in the original source were converted using the molar density of water vapor in air at $25^{\circ} \mathrm{C}$ after Oren et al. [2].

Our analysis is restricted to closed canopies because trees in open canopies are more likely to have a conical or complicated branch architecture, which weakens the link between $h$ and mean path length. We also excluded data from manipulation experiments because sapwood permeability and $A_{S} / A_{L}$ may respond to abrupt changes in nutrient or light regimes, achieved through fertilization [27,39], stand density reduction [40], $\mathrm{CO}_{2}$ enrichment $[41,42]$, and foliage removal $[43,2]$, and the adjustment to new 
conditions may take several years. In nearly all these studies, $G_{\text {sref }}$ is normalized by maximum projected leaf area in the growing season, and $A_{S} / A_{L}$ represents the ratio of sapwood-to-leaf area at breast height to projected leaf area during the growing season. However, we did not exclude studies that reported estimates of these parameters derived from total as opposed to projected leaf area [27], or studies for which sapwood area estimates are taken from a different height [44], to maximize the sample size in Table 1. No other exclusionary criteria were employed in this survey.

The variables of interest were treated as canopy averages in these surveys. In the cases where data were reported for individual trees or species, canopy averages were calculated by weighting individual- or species-specific values according to their $L A I$.

\subsection{Survey 2: Allometric equations for $A_{S} / A_{L}$}

In a second literature survey, the slope and intercept of the change in $A_{S} / A_{L}$ with $h$ were compiled from studies on 21 closedcanopy forest ecosystems (Survey 2, Table 2), representing different species growing in a broad range of climates. We used the estimates of canopy-averaged values of $A_{S} / A_{L}$ and $h$ along chronosequence stages, as well as whole-tree estimates of $A_{S} / A_{L}$ for trees of different heights in the same stand. The same exclusionary criteria employed for Survey 1 were employed for Survey 2. Survey 2 is similar to a survey conducted by McDowell et al. [31] yet less than a quarter of the studies cited in Table 2 are common to both surveys. However, in this study, we expanded considerably the sample size and the number of sites which have a negative relationship between $A_{S} / A_{L}$ and $h$ (i.e. negative $\alpha$ ).

\subsubsection{Statistical tests and optimization}

Statistical performance indicators such as the correlation coefficient $\left(r^{2}\right)$ and $t$-statistics for slope significance (i.e. $P$ ) were performed in Matlab version 6.0. Because correlation coefficients are often compared between datasets of different sample sizes in this study, adjusted $R^{2}$ is used. Unless otherwise stated, slope significance was interpreted using two-tailed $t$-tests with a null hypoth- esis of zero slope. When necessary, nonlinear optimization was performed in Matlab using the Gauss-Newton algorithm [45].

\section{Results}

\subsection{Changes in $G_{\text {sref }}$ with $A_{S} / A_{L}$ and $h$}

Using Eq. (3) along with simplifications leading to Eq. (6), $G_{\text {sref }}$ was shown to be analytically related to the product of $A_{S} / A_{L}$ and $h^{-1}$, a finding that appears to be accurate across the 29 sites for which all three variables were available (Survey 1, Table 1, Fig. 2). A simple linear regression of these variables gives:

$G_{\text {sref }}=98.2 \frac{A_{S}}{A_{L} h}+37.3$,

with $r^{2}=0.75$ and $P<0.0001$. Separating the relative importance of $A_{S} / A_{L}$ and $h^{-1}$, we find that approximately $27 \%$ of the variability in $G_{\text {sref }}$ is driven by $A_{S} / A_{L}(P<0.01)$ and $46 \%$ is driven by $h^{-1}(P<0.0001)$. The relationship is also quite strong when reference canopy rates uncorrected for high $L A I$ are considered (inset to Fig. $2, r^{2}=0.73, P<0.0001$ ).

The sites in the above analysis included 19 temperate, seven boreal and three tropical forest ecosystems. The small sample size of boreal and tropical forest sites prevents this relationship from being analyzed within each of these climatically distinct subsets. However, in temperate sites, the slope of the relationship $\left(G_{\text {sref }}=95.8 \frac{A_{S}}{A_{L} h}+43.2, r^{2}=0.92\right)$ is not statistically distinguishable from the slope derived with data from all three climate zones $(P=0.81)$.

Among the 29 sites, seven are dominated by $P$. abies, three are dominated by $P$. mariana, and two each are dominated by Cryptomeria Japonica, $P$. pinaster, $P$. taeda, E. saligna, and P. sylvestris. To assess the influence of replicates of single species, a replication analysis procedure proposed by McDowell et al. [31] was adopted. Specifically, the analysis was repeated for 672 unique combinations of sites such that no more than one site dominated by each species was included. Each combination resulted in a positive slope

Table 2

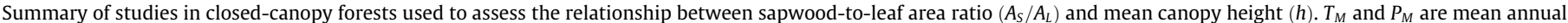

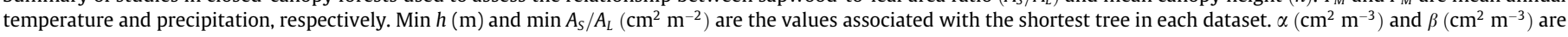

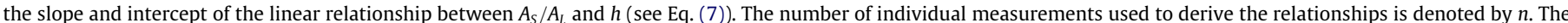

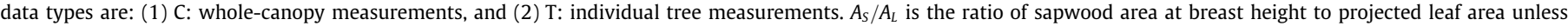
otherwise noted.

\begin{tabular}{|c|c|c|c|c|c|c|c|c|c|c|c|}
\hline Species & Family & Location & $T_{M}$ & $P_{M}$ & $\operatorname{Min} h$ & $\operatorname{Min} A_{S} / A_{L}$ & $\alpha$ & $\beta$ & $n$ & Data type & Reference \\
\hline Abies balsamea & Pinaceae & $46-49 \mathrm{~N}, 65-73 \mathrm{~W}$ & $\sim 4$ & 1000 & 2 & 2.61 & -0.14 & 3.61 & 56 & $\mathrm{C}$ & [73] \\
\hline Abies balsamea & Pinaceae & $44.9 \mathrm{~N}, 68.6 \mathrm{~W}$ & 6.6 & 1060 & 7.6 & 0.76 & 0.13 & 0.39 & 3 & $\mathrm{~T}$ & [74] \\
\hline Abies lasiocarpa & Pinaceae & $46-47 \mathrm{~N}, 114 \mathrm{~W}$ & 2 & 720 & 3.8 & 0.31 & 0.06 & 0.24 & 9 & $\mathrm{~T}$ & [75] \\
\hline Eucalyptus delegatensis & Myrtaceae & $35.7 \mathrm{~S}, 148.5 \mathrm{E}$ & 9.5 & 1400 & 3 & 2.62 & -0.04 & 3.25 & 23 & $\mathrm{~T}$ & [76] \\
\hline Eucalyptus saligna & Myrtaceae & $19.8 \mathrm{~N}, 155.1 \mathrm{~W}$ & 21 & 4000 & 7 & 0.68 & 0.06 & 0.27 & 2 & C & [19] \\
\hline Fagus sylvatica & Fagaceae & $55.0 \mathrm{~N}, 10.5 \mathrm{~W}$ & 7.5 & 750 & 11 & 2.83 & 0.16 & 1.5 & 9 & $\mathrm{~T}$ & [4] \\
\hline Larix occidentalis & Pinaceae & $46-47 \mathrm{~N}, 114 \mathrm{~W}$ & 7.2 & 430 & 11 & 2.44 & -0.05 & 4.2 & 11 & $\mathrm{~T}$ & [75] \\
\hline Picea abies & Pinaceae & $50.2 \mathrm{~N}, 11.9 \mathrm{E}$ & 5.8 & 1100 & 14.7 & 3.55 & -0.13 & 5.8 & 6 & $\mathrm{C}$ & [49] \\
\hline Picea abies & Pinaceae & $64.1 \mathrm{~N}, 19.3 \mathrm{E}$ & 2 & 600 & 8.73 & 3.27 & -0.72 & 11.47 & 6 & $\mathrm{~T}$ & [58] \\
\hline Picea mariana & Pinaceae & $55.9 \mathrm{~N}, 90.3 \mathrm{~W}$ & 0.8 & 440 & 2.8 & $0.8^{\mathrm{a}}$ & -0.41 & 6.1 & 19 & $\mathrm{~T}$ & [27] \\
\hline Picea sitchensis & Pinaceae & $53.0 \mathrm{~N}, 7.3 \mathrm{~W}$ & 9.3 & 850 & 4.4 & 1.82 & 0.03 & 3.6 & 6 & C & [77] \\
\hline Pinus albicaulis & Pinaceae & $46-47 \mathrm{~N}, 114 \mathrm{~W}$ & 2 & 720 & 3.5 & 2.28 & -0.28 & 7.63 & 14 & $\mathrm{~T}$ & [78] \\
\hline Pinus monticola & Pinaceae & $48.4 \mathrm{~N}, 116.8 \mathrm{~W}$ & 6.6 & 810 & 5 & 2.98 & 0.08 & 2.89 & 21 & $\mathrm{~T}$ & {$[78,79]$} \\
\hline Pinus ponderosa & Pinaceae & $48.4 \mathrm{~N}, 116.8 \mathrm{~W}$ & 6.6 & 810 & 4 & 5.71 & 0.16 & 9.33 & 22 & $\mathrm{~T}$ & {$[78,79]$} \\
\hline Pinus ponderosa & Pinaceae & $46-47 \mathrm{~N}, 114 \mathrm{~W}$ & 7.2 & 430 & 13.2 & 5.97 & 0.01 & 5.74 & 11 & $\mathrm{~T}$ & [75] \\
\hline Pinus sylvestris & Pinaceae & $53.4 \mathrm{~N}, 0.65 \mathrm{E}$ & 10 & 550 & 8 & $9.31^{\mathrm{b}}$ & 0.17 & 7.6 & 5 & $\mathrm{C}$ & [32] \\
\hline Pinus sylvestris & Pinaceae & $57.3 \mathrm{~N}, 4.8 \mathrm{~W}$ & 6.5 & 1215 & 4 & 5.77 & 0.22 & 7.86 & 19 & $\mathrm{~T}$ & [80] \\
\hline Pseudotsuga menziesii & Pinaceae & $45.8 \mathrm{~N}, 122.0 \mathrm{~W}$ & 8.7 & 2500 & 15 & 1.93 & 0.01 & 1.7 & 3 & C & [13] \\
\hline Pseudotsuga menziesii & Pinaceae & $48.4 \mathrm{~N}, 116.8 \mathrm{~W}$ & 6.6 & 810 & 6 & 2.94 & 0.01 & 3.02 & 23 & $\mathrm{~T}$ & {$[9,10]$} \\
\hline Pseudotsuga menziesii & Pinaceae & $46-47 \mathrm{~N}, 114 \mathrm{~W}$ & 7.2 & 434 & 11 & 1.95 & -0.17 & 2.04 & 17 & $\mathrm{~T}$ & [50] \\
\hline Quercus garryana & Fagaceae & $44.6 \mathrm{~N}, 123.3 \mathrm{~W}$ & 11 & 1100 & 10 & 4.34 & -0.11 & 5.4 & 2 & C & [16] \\
\hline
\end{tabular}

\footnotetext{
a Ratio of sapwood area to total leaf area.
}

b Sapwood-to-leaf area averaged over the entire stem. 


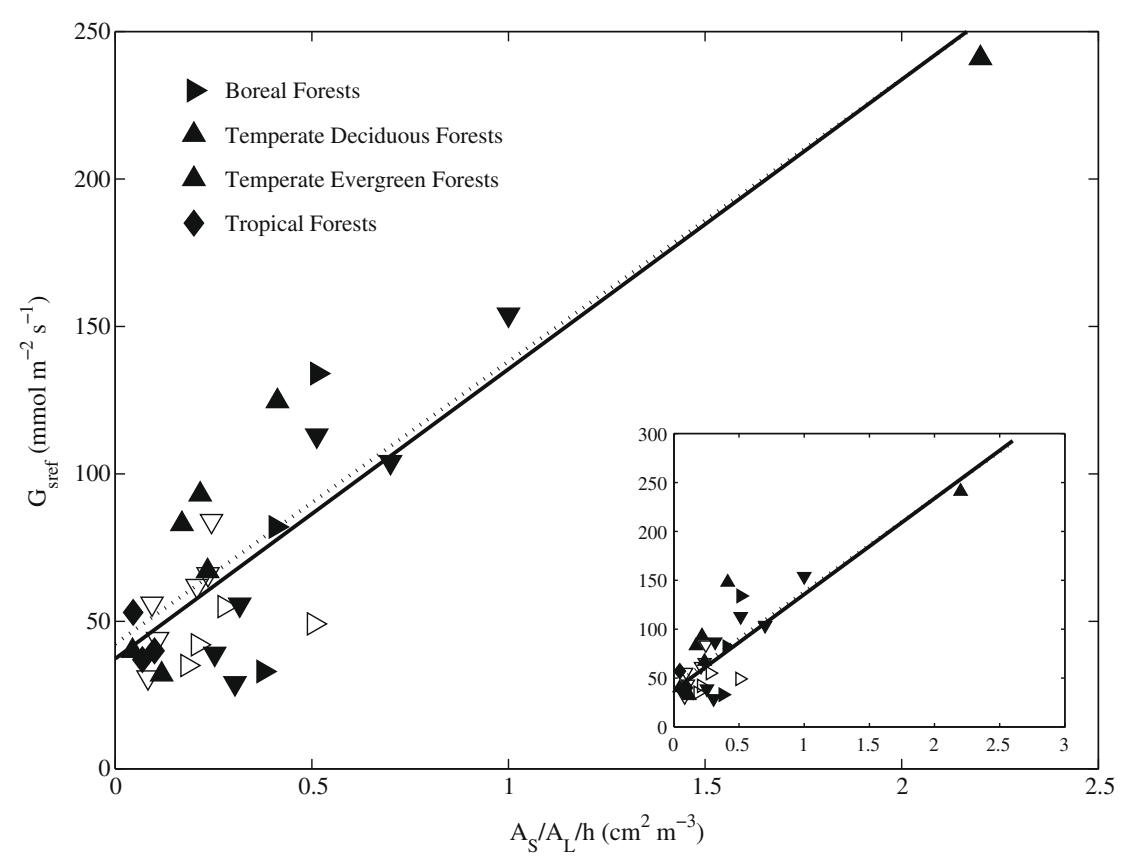

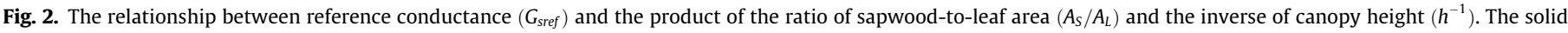

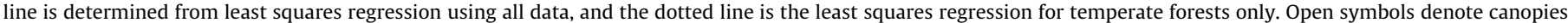

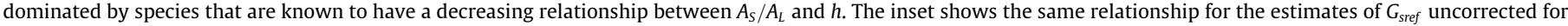
high $L A I$ as described in Section 3.

(ranging 92.5-98.4 mmol m $\mathrm{m}^{-1} \mathrm{~s}^{-1}$ ) that was statistically different from zero $(P<0.0001$ for all combinations). Furthermore, none of the slopes differed significantly from the slope derived from the entire dataset $(P>0.6$ for all combinations).

A weak relationship between $G_{\text {sref }}$ and $h^{-1}$ emerged when analyzing all 42 datasets presented in Table $1\left(r^{2}=0.24, P<0.001\right) . G_{\text {sref }}$ and $h^{-1}$ weremoresignificantly correlated whentemperatesiteswere analyzed separately. Across temperate sites, reference conductance increased strongly with $h^{-1}\left(r^{2}=0.68, P<0.0001\right.$, Fig. 3a). Again adopting the analysis replication procedure (giving 192 unique com- binations), we found that the relationship between $G_{\text {sref }}$ and $h^{-1}$ was significant for all combinations of sites in which only one stand of each species was represented ( $P<0.001$ for all combinations). This relationship, however, is driven strongly by the data from the $4 \mathrm{~m}$ hedgerow stand (Table 1). Excluding this site from the analysis, the increase in $G_{\text {sref }}$ with $h^{-1}$ was significantly different from zero (at the $95 \%$ confidence level) for all combinations that included the $6.8 \mathrm{~m} \mathrm{P}$. taeda stand.

Among tropical species, $h^{-1}$ explained $19 \%$ of the variance in $G_{\text {sref }}$, although the slope is not statistically significant (Fig. 3b,

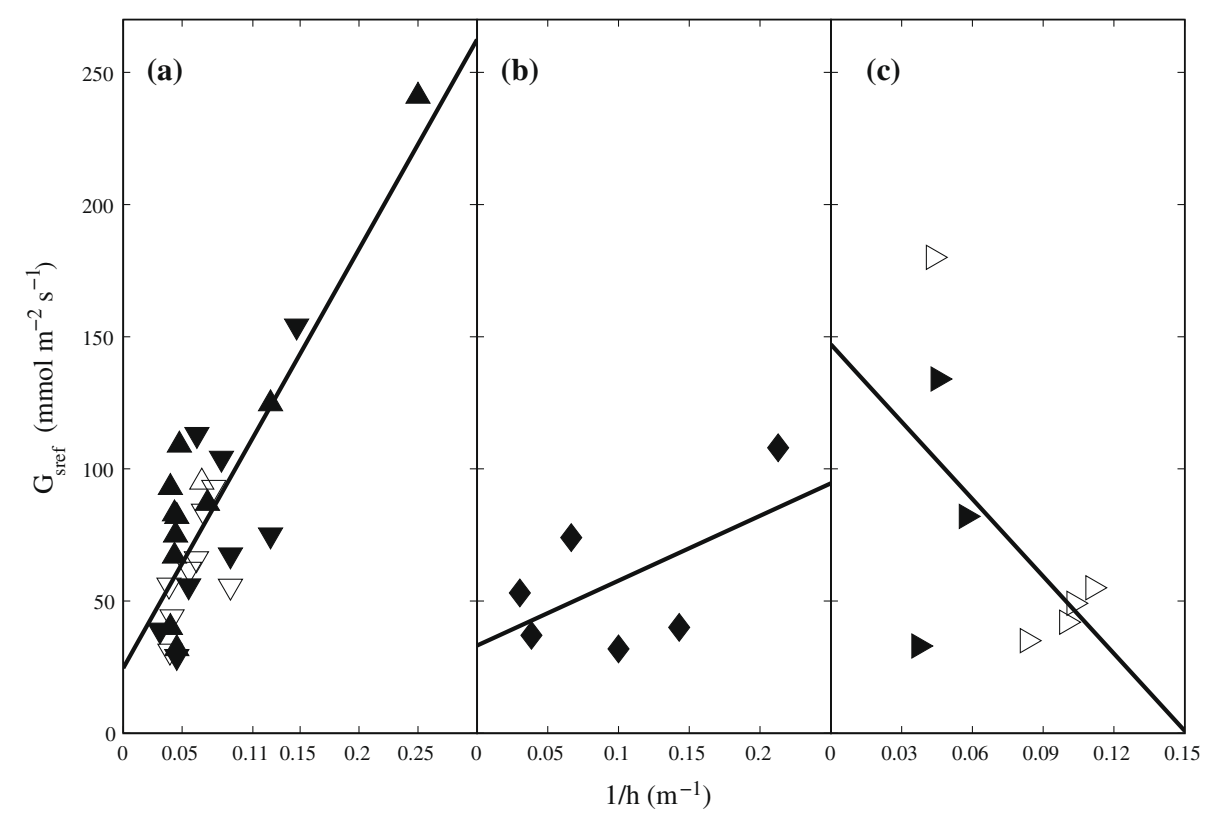

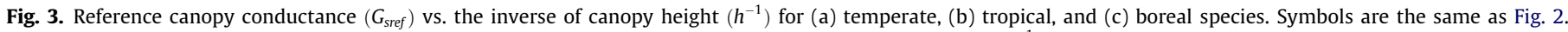
Regression lines are not shown for tropical and boreal sites as no significant relationships between $G_{\text {sref }}$ and $h^{-1}$ emerged for these small samples. 
$P=0.17)$. The tropical subset includes two $E$. saligna stands, but repeating the analysis using one or the other of these sites resulted in a derived slope that was statistically indistinguishable from the slope calculated from all tropical sites.

$G_{\text {sref }}$ decreased weakly and insignificantly with $h^{-1}$ among the boreal sites (Fig. $3 c, r^{2}=0.18, p=0.17$ ) though the decrease is significant for some combinations of boreal sites that included only one representation of each species. This negative relationship is driven by reference conductance rates of $P$. mariana (i.e. - the three boreal sites with the highest value of $\left.A_{S} / A_{L} / h\right)$. $P$. mariana has a strongly decreasing $\alpha$ [27], and would be expected to have relatively low reference conductance rates.

Roughly $50 \%$ of the studies considered in Survey 1 are from the Pinacaea family. Therefore, for the significant relationships that emerged from this analysis (i.e. Figs. 2 and 3a), we conducted two additional tests to assess the impact of phylogenetic similarities among the ecosystems: (1) we performed an additional replication analysis procedure whereby the relationships were assessed for unique combinations of sites such that no more than one species from each family was represented, and (2) the relationships were derived independently for angiosperms and gymnosperms. For the relationship between $G_{s r e f}$ and $A_{S} / A_{L} / h$ shown in Fig. 2, all 512 unique combinations resulted in a statistically significant slope $(P<0.001)$ with a high degree of correlation $\left(r^{2}=0.79-0.91\right)$. The correlation for the relationship derived with angiosperms alone $\left(G_{\text {sref }}=45.0 \frac{A_{S}}{A_{L} h}+71.1\right)$ improved significantly when compared to the relationship derived with gymnosperms alone $\left(r^{2}=0.92\right.$ and 0.78 , respectively), though we note that this higher correlation is driven strongly by the reference canopy rate in the 4-m hedgerow (an angiosperm site). For the relationship between $G_{\text {sref }}$ and $1 / h$ among temperate forests (Fig. 3a), all 1008 unique combinations resulted in statistically significant slopes $(P<0.01)$. The amount of variance in $G_{\text {sref }}$ explained by $1 / h$ is higher for angiosperms alone $\left(r^{2}=0.92\right)$, though again, this relationship is driven strongly by the hedgerow.

Finally, because reference conductance rates have previously been shown to vary with leaf area within species, we also assessed the generality of this relationship. Total reference conductance (i.e. reference conductance per unit ground area) should increase with $L A I$; however, due to the saturation of canopy light absorption at high $L A I$, reference conductance per unit leaf area should decrease with $L A I$. A significant but very weak linear negative relationship between $G_{\text {sref }}$ and $L A I$ was observed based on the 42 sites of Survey $1\left(r^{2}=0.08, P<0.05\right.$, Fig. 4$)$, with correlation improving slightly for the relationship between $G_{\text {sref }}$ and $\log (L A I)\left(r^{2}=0.10\right)$.

\subsection{Relationship between $A_{S} / A_{L}$ and $h$}

The linear relationship between $A_{S} / A_{L}$ and $h$ compiled from the literature varied considerably among the 21 sites considered in Survey 2 (Table 2). A majority of the studies reported a positive linear relationship, though due to the presence of some strongly negative slopes, the overall mean values were $\bar{\alpha}=-0.03$ and $\bar{\beta}=4.3$, with standard deviations of $\sigma_{\alpha}=0.18$ and $\sigma_{\beta}=2.65$, respectively. To determine whether this variation is sufficient to explain the variation observed in the general relationship between $G_{\text {sref }}$ and $h$ (Fig. 3), the quantity $G_{\text {sref }} \approx(\bar{\alpha} h+\bar{\beta}) \frac{1}{h}$ was referenced to the conductance data by minimizing the standard error between this quantity and the measurements (Fig. 5). This model clearly accounts for very little of the variability; however, more than $70 \%$ of the data points fall within the range of expectation bounded by $G_{\text {sref }} \approx\left(\left(\bar{\alpha} \pm \sigma_{\alpha}\right) h+\bar{\beta}\right) \frac{1}{h}$ (shaded area in Fig. 5), suggesting that much of the observed variability in $G_{\text {sref }}$ may be explained by the large variations of $\alpha$ among species.

The mean values $\bar{\alpha}$ and $\bar{\beta}$ did not change significantly when the analysis was repeated to eliminate multiple data sets of one spe-

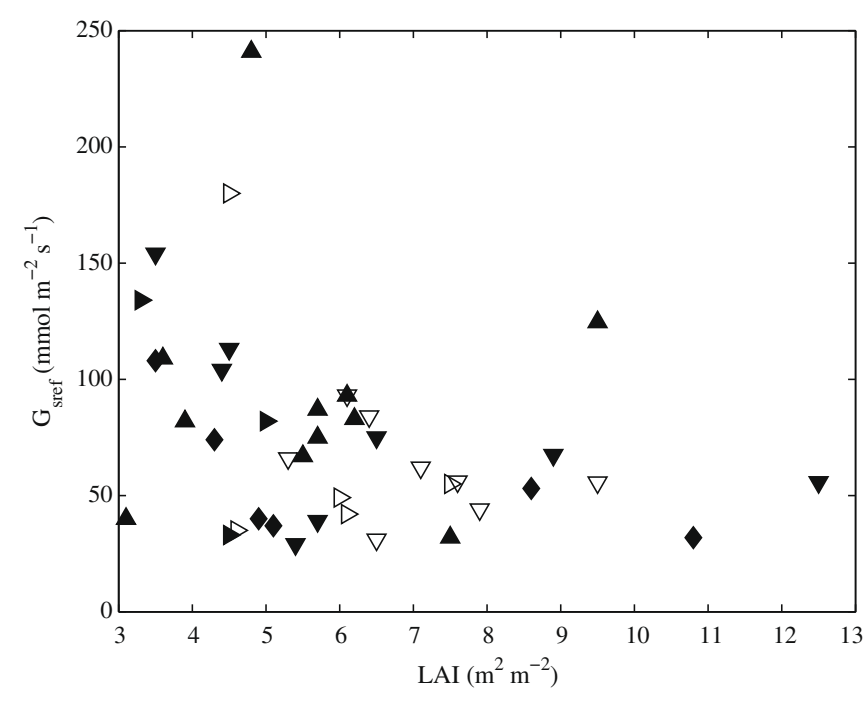

Fig. 4. Reference canopy conductance $\left(G_{\text {sref }}\right)$ as a function of leaf area index $(L A I)$ for all sites in Table 1. Symbols are the same as those shown in Fig. 2.

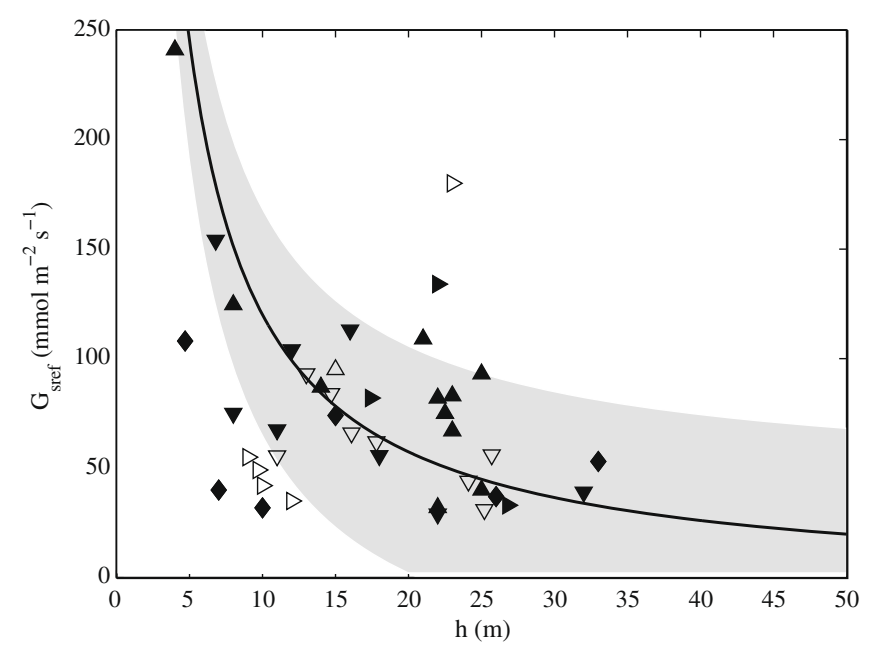

Fig. 5. Reference canopy conductance $\left(G_{\text {sref }}\right)$ vs. canopy height $(h)$ for all sites from Table 1 . The dotted line represents the quantity $G_{\text {sref }} \approx(\bar{\alpha} h+\bar{\beta}) \frac{1}{h}$ referenced to the conductance data by minimizing the standard error $\left(r^{2}=0.24, P<0.001\right)$, where $\bar{\alpha}$ and $\bar{\beta}$ are the average slope and intercept, respectively of the relationships presented in Table 2 . The shaded area represents the range of expectation bounded by $G_{\text {sref }} \approx\left(\left(\bar{\alpha} \pm \sigma_{\alpha}\right) h+\bar{\beta}\right) \frac{1}{h}$, where $\sigma_{\alpha}$ is the standard deviation of the slopes $(\alpha)$ presented in Table 2. Symbols are the same as those shown in Fig. 2.

cies. Furthermore, the mean values of $\alpha$ and $\beta$ for relationships derived using whole-canopy values of $A_{S} / A_{L}$ and $h$ among chronosequences $\left(\overline{\alpha_{c h r}}=-0.015, \overline{\beta_{c h r}}=4.0\right)$ were statistically indistinguishable from the mean values of $\alpha$ and $\beta$ for relationships derived using measurements of $A_{S} / A_{L}$ and $h$ on individual trees within a single stand $\left(\overline{\alpha_{\text {stand }}}=-0.030, \overline{\beta_{\text {stand }}}=4.3\right)$ using a $t$-test for differences between the means assuming unknown but equal variances.

The slope factor $\alpha$ was not related to mean annual precipitation (which can be considered a proxy for soil water availability) across sites, consistent with the previous inter-specific observations [31] and with the previous finding that $\alpha$ was indistinguishable between xeric and mesic P. palustris stands [13]. However, $\alpha$ increases significantly with the natural log of mean annual temperature $\left(T_{M}\right.$, Fig. $\left.\quad 6, \quad r^{2}=0.39, P<0.01\right)$, consistent with the previous observations of a significant relationship between $T_{M}$ and $\alpha$ among 


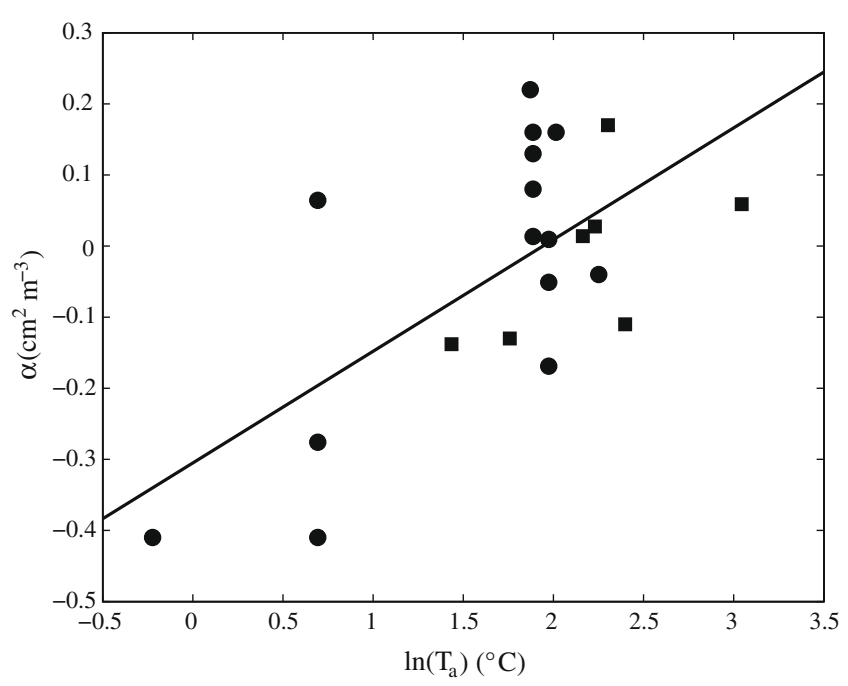

Fig. 6. The change in $A_{S} / A_{L}$ with $h(\alpha)$ as a function of the natural log of mean annual temperature $\left(r^{2}=0.39, P<0.01\right)$ for the studies presented in Table 2. Circles represent relationships derived from whole-tree measurements, and squares represent relationships derived from whole-canopy measurements.

mature $P$. sylvestris stands [18], though much of the variation in $\alpha$ is not explained by temperature.

\section{Discussion}

\subsection{The hydraulic controls on stomatal conductance across species}

In 1997, Ryan and Yoder [46] proposed that the nearly universal declines in tree growth with forest age may be related to decreasing stomatal conductance as trees grow taller and hydraulic resistance to water flow increases with the transport path length. Since then, numerous analysis and experiments have been conducted to test this so-called "hydraulic limitation hypothesis". Some experiments support the hypothesis $[14,4,15,12,47,5,13]$, while others suggest that $A_{S} / A_{L}$ is more important than $h$ in controlling stomatal conductance $[17,18,39,27]$, and some point to the importance of age or size-related changes in physiology $[48,19]$. Our results confirmed the importance of homeostatic changes in both $h$ and $A_{S} / A_{L}$ to the whole-plant water balance. We found only a weak general relationship between reference conductance and height alone among 42 forested ecosystems representing a large number of species from a wide range of climates, although a strong relationship exists within the better represented temperate climate subset (Fig. 3a). Adding $A_{S} / A_{L}$ to $h$ explains $75 \%$ of the variation in $G_{\text {sref }}$ among 29 sites representing a wide range of biomes (Fig. 2). This degree of explanatory power exceeded that predicted by the theoretical arguments of Section 2, which projected equal influence of $k_{S}\left(\Psi_{\text {leaf }}-\rho_{w} g h\right)$ and $A_{S} / A_{L} / h$ on $G_{\text {sref. }}$. That $A_{S} / A_{L} / h$ eclipses $k_{s}\left(\Psi_{\text {leaf }}-\rho_{w} g h\right)$ in terms of impact on reference conductance rates across species suggests compensatory interactions between $k_{s}$ and $\Psi_{\text {leaf }}$ limiting the range of $k_{s}\left(\Psi_{\text {leaf }}-\rho_{w} g h\right)$ that may exist across species, or that these interactions are mediated by height or $A_{S} / A_{L}$.

Many of the species considered in Survey 1 are phylogenetically similar, and over half are from the family Pinacaea. The significant relationships that emerged from these surveys remain relatively unchanged when only one representative of each species or family is considered in the analysis, and the dataset is more largely limited by a paucity of data from short forests as the correlations for the relationships in Figs. 2 and 3a are driven strongly by the two shortest canopies (i.e. the $4 \mathrm{~m}$ hedgerow stand and the $6.8 \mathrm{~m}$ P. taeda stand). Short stands, in addition to being underrepresented in this dataset, are also more subject to biases associated with equating path length to $h$. As demonstrated in Fig. 1, neglecting rooting length in short canopies results in an overestimation of the product $A_{S} / A_{L} / h$ on the order of $10-20 \%$. Conversely, canopy architecture patterns may be significantly different in shorter stands (i.e. more branching) such that $h$ may either over or under-estimate path length. While the results shown in Figs. 2 and 3a are robust and remain highly significant when the assumed height of these two shortest stands is altered by $\pm 2 \mathrm{~m}$, an overestimation of canopy height in these stands may suggest a relationship between $G_{\text {sref }}$ and $A_{S} / A_{L} / h$ or $1 / h$ that is linear when a saturating function is actually a better model.

We also note that the estimates of $G_{\text {sref }}$ extracted from the literature for Survey 1 are subjective estimates determined using a range of regression and modelling procedures that vary from study to study. However, the high correlation between these estimates and $A_{S} / A_{L} / h$ suggests that the error associated with difference in methodology between the studies is relatively small.

\subsection{Mechanisms and limits to hydraulic compensation within species}

To assess the predictive ability of this model within a species, the four sites for which changes in $G_{\text {sref }}$ and $A_{S} / A_{L}$ were reported for trees or stands of different heights were further explored. These were Eucalpytus saligna [19], F. sylvatica [4], P. abies [49], and $P$. mariana [27]. Following the sensitivity analysis presented in the Appendix, the quantity $1 /\left(1-\rho_{w} g h\left(\Psi_{\text {leaf }}\right)^{-1}\right)$ can be assumed to equal unity for a wide range of ecosystems, noting that $\rho_{w} \approx 10^{3} \mathrm{~kg} \mathrm{~m}^{-3}, \mathrm{~g} \approx 10 \mathrm{~m} \mathrm{~s}^{-2}$, and $\Psi_{\text {leaf }} \approx 10^{6} \mathrm{~kg} \mathrm{~m}^{-2} \mathrm{~s}$. This approximation can be used to explicitly assess the relative contribution of $\partial h / h$ and $\frac{\partial A_{S} / A_{L}}{A_{S} / A_{L}}$ to $\partial G_{\text {sref }} / G_{\text {sref }}$ within a species (Table 3 ). For the four datasets, the relative change in $A_{S} / A_{L}$ is insufficient to compensate for the observed reductions in conductance with increasing height. For E. saligna and F. sylvatica, the ratio of the relative change in $A_{S} / A_{L}$ to the relative change in $h$ is 0.64 and 0.41 , respectively. For $P$. mariana and $P$. abies, the observed decreases in $A_{S} / A_{L}$ with height compounds the relative decreases in $G_{s r e f}$ observed in taller stands.

Spruce and fir species often exhibit negative relationships between $A_{S} / A_{L}$ and $h[12,31,27]$, which confers no known hydraulic advantage. It was proposed that this negative relationship may reflect a longer period of juvenile wood development, which has lower conductivity than latewood [50], or increased leaf life span, which would increase nutrient recycling in poor quality sites [31]. The latter hypothesis is supported in part by the observation that $\alpha$ is related across species to the site quality [31], which reflects, among other factors, the effect of site nutrient availability on growth.

The relative rates of change shown in Table 3 can also be used to assess the assumptions of the proposed model for $G_{\text {sref }}$. For F. sylvatica and $P$. mariana, the ratio of the relative change in $G_{s r e f}$ to the quantity $\frac{\Delta A_{S} / A_{L}}{A_{S} / A_{L}}-\Delta h / h$ is close to 1 ( 0.93 and 1.13 , respectively), which suggests that the assumptions in this model are correct. However, the predicted change in conductance for $P$. abies

Table 3

The relative change in conductance $\left(G_{s}\right)$, height $(h)$, and sapwood-to-leaf area ratio $\left(A_{S} / A_{L}\right)$ for the four ecosystems in Table 1 for which all three variables were available at various heights.

\begin{tabular}{lllcl}
\hline & $\frac{\Delta G_{\text {Sref }}}{G_{\text {Sref }}}$ & $\frac{\Delta h}{h}$ & $\frac{\Delta A_{S} / A_{L}}{A_{S} / A_{L}}$ & $\frac{\Delta A_{S} / A_{L}}{A_{S} / A_{L}}-\frac{\Delta h}{h}$ \\
\hline Eucalpytus saligna & -0.1 & 2.6 & 1.7 & -0.9 \\
Fagus sylvatica & -1.6 & 2.5 & 1.0 & -1.4 \\
Picea abies & -0.6 & 0.7 & -0.4 & -1.1 \\
Picea mariana & -0.2 & 0.1 & -0.2 & -0.3 \\
\hline
\end{tabular}


$(-1.11)$ and E. saligna $(-0.93)$ is inconsistent with the observed relative decrease ( -0.6 and -0.1 , respectively), which indicates that, in some species, compensatory mechanisms other than $A_{S} / A_{L}$ and $h$ may represent important controls on reference stomatal conductance. Other compensatory changes may include height-related increases in sapwood permeability [51], decreases in leaf water potential $[52,53,19]$, increased reliance on stored water [47], increased allocation to fine roots [32], and changes in crown architecture such as increased branching and decreased stem diameter [54]. Data on these homeostatic mechanisms are scarce and do not support an analysis of a general relationship.

\subsection{Variation in the rate of change of $A_{S} / A_{L}$ with height}

The primary result from Survey 1 is Eq. (9), which shows that when $A_{S} / A_{L}$ and $h$ are measured or independently estimated, $G_{\text {sref }}$ can be well reproduced, though $h$ alone appears to be a good predictor for temperate species. However, as we have stated before, $A_{S} / A_{L}$ and $h$ are typically not independent within species, and may not be independent among species. Hence, Survey 2 was conducted to assess whether variations in $h$ may provide prognostic information about variations in $A_{S} / A_{L}$.

The change in sapwood-to-leaf area ratio with height varies considerately among the species of Survey 2, with the rate of change ranging from $-0.72 \mathrm{~cm}^{2} \mathrm{~m}^{-3}$ in $P$. abies to $0.21 \mathrm{~cm}^{2} \mathrm{~m}^{-3}$ in P. sylvestris [32]. A mechanistic model for this variation would greatly enhance the generality of the derived relationship between $G_{\text {sref }}, h$ and $A_{S} / A_{L}$, (Fig. 2, Eq. (9)). While a significant relationship emerged from Survey 2 between $\alpha$ and mean annual temperature, we do not believe that this relationship is strong enough for general application at this time. In this section, some additional likely controls on height related changes in $A_{S} / A_{L}$ are discussed.

McDowell et al. [31] observed that in species exhibiting a positive relationship between $A_{S} / A_{L}$ and $h, \alpha$ was approximately an order of magnitude higher in vessel bearing species when compared to tracheid bearing species. In species having such positive relationships among those assembled for our analysis, we found that the mean rate of change was only marginally higher in vessel bearing species $\left(\bar{\alpha}_{\text {vessel }}=0.018 \mathrm{~cm}^{2} \mathrm{~m}^{-3}\right)$ than tracheid bearing species $\left(\bar{\alpha}_{\text {tracheid }}=-0.045 \mathrm{~cm}^{2} \mathrm{~m}^{-3}\right)$. Positive and negative values of $\alpha$ were reported for both tracheid and vessel bearing species, and the average rate of change for each functional type was statistically indistinguishable from the average rate of change for all species according to a $t$-test for differences between the means assuming unknown but equal variances (null hypothesis of equivalent means). This rate of change also varies across sites occupied by the same species. For example, the values of $\alpha=0.01$ and $\alpha=-0.17 \mathrm{~m}^{2} \mathrm{~m}^{-3}$ were reported for Pseudotsuga menziesii stands, and considerable variation in $\alpha$ among $P$. sylvestris and $P$. ponderosa has also been observed (see [31]). Thus, a simple categorization into plant functional type, or even analysis limited to a species, does not introduce much 'prognostic' utility for specifying the rate of change of $A_{S} / A_{L}$ with height.

The lack of similarity in the sensitivity of $A_{S} / A_{L}$ to $h$ within plant functional types or within a species suggests that climatic controls may influence inter-site differences in $\alpha$. Additionally, the fact that we failed to find a strong relationship between $G_{\text {sref }}$ and $h$ among all sites in the dataset, but observed significant relationships within the temperate zone suggests that $A_{S} / A_{L}$ reflects the prevailing climate conditions. Examination of Eq. (4) shows that acclimation for the purpose of sustaining $G_{s r e f}$ in dry climates could be achieved through a proportional increase in $A_{S} / A_{L}$ with $D$. While long-average $D$ was not available for most of the sites considered in this study, the observed relationship between $\alpha$ and $T_{M}$ could imply a relationship between $\alpha$ and $D$, as long-term average vapor pressure deficit and temperature are correlated across ecosystems that are not persistently water limited. In other studies, this theoretical prediction has been confirmed for P. sylvestris [18] and other species of the genus Pinus [55], though no relationship between $D$ and $A_{S} / A_{L}$ was observed among other conifer species (i.e., Abies and Picea spp., P. menziesii [55]).

Lastly, the light environment may influence the rate in which sapwood-to-leaf area ratio changes with height even within closed canopies [56]. No significant differences in $\alpha$ were observed between canopy-level values obtained along chronosequences of closed-canopy stands and tree-level values obtained from measurements in single stands. Because the average light environment is similar among closed-canopy stands in a chronosequence but the light environment of individual crowns varies considerably depending on position in the canopy, the similarity of average $\alpha$ in these two situations implies that the rate of change of $A_{S} / A_{L}$ with $h$ is not strongly related to light availability. Indeed, the values of $\alpha$ for open stands (i.e. $L A I<3.0 \mathrm{~m}^{2} \mathrm{~m}^{-2}$ ) of Pinus ponderosa $\left(\alpha=0.17 \mathrm{~cm}^{2} \mathrm{~m}^{-3},[14]\right), P$. sylvestris $\left(\alpha=0.16 \mathrm{~cm}^{2} \mathrm{~m}^{-3}\right.$, [5]), and $P$. palustris $\left(\alpha=0.21 \mathrm{~cm}^{2} \mathrm{~m}^{-3},[13]\right)$ are well within the range of variation observed for closed stands. In summary, future research on the sensitivity of $A_{S} / A_{L}$ to $h$ should focus on the potential impacts of climate conditions and perhaps also soil nutrient regimes, which were not explicitly considered here.

\subsection{Broader implications for ecosystem-to-regional scale carbon and water cycle modeling}

The response of canopy conductance to rapid changes in environmental drivers is often described with Jarvis-type multiplicative functions applied to a species-specific reference state (here $G_{\text {sref }}$ ). Because the Jarvis model and its variants are widely used, much effort has been invested in deriving generic representations of the model's reduction functions. For example, Oren et al. [2] showed that across a wide range of boreal to tropical species the sensitivity of $G_{s}$ to $D$ can be well described by the function $f_{2}(D)=1-0.6 \ln (D)$. Generic relationships for the light and soil water response functions have also been developed using datasets for a broad range of species [1]. Therefore, a representation for $G_{\text {sref }}$ that explains inter-site variability can be used in coordination with these generic reduction functions to specify canopy conductance rates a priori for a wide range of ecosystems at a high temporal resolution.

Our results suggest that differences among species in leaf physiology and the anatomy of the transport tissue, and differences in soil properties among sites, may exert a smaller effect on $G_{\text {sref }}$ relative to the direct effects of canopy architecture, and that height and sapwood-to-leaf area ratio explain most (75\%) of the variation in $G_{\text {sref }}$ among closed-canopy ecosystems. To our knowledge, only one other attempt was made to derive a generic formulation for reference conductance, in which total canopy conductance at a reference state (i.e. $G_{T r e f}$ ) was related to $L A I$ [1]. In that study, which considered a wide range of forested ecosystems $(n=18), G_{T r e f}$ increased linearly with $L A I$, saturating at about the midpoint of the LAI range. Here, the observed relationship between $G_{\text {sref }}$ and LAI $\left(r^{2}=0.10\right)$ is much weaker than the observed relationship of $G_{\text {sref }}$ to $A_{S} / A_{L} / h\left(r^{2}=0.75\right)$ proposed here.

For this parsimonious formulation to have prognostic utility at coarse spatial scales, $A_{S} / A_{L}$ must be specified. At the ecosystem scale, this hydraulic characteristic is relatively simple to estimate when compared to the effort required to collect eddy-covariance or sap flux data and the suite of meteorological measurements typically required to estimate $G_{\text {sref }}$ at single stand. At the landscape scale, sapwood area may be estimated for monospecific stands with well-established allometric relationships with height or basal area measurements [57], both of which can be derived with reasonable accuracy from LIDAR measurements $[11,9,10]$. However, 
we do not at this time know of a generic, prognostic model for $A_{S} / A_{L}$ that would facilitate the application of Eq. (9) over coarse spatial scales (i.e. regional), though our results suggest limatic mediation of the relationship between $A_{S} / A_{L}$ and $h$ that could motivate future research. Finally, we did find a strong relationship between $G_{\text {sref }}$ and $h$ within temperate forests that could be more immediately useful in coarse-scale modelling efforts.

\section{Acknowledgements}

Support was provided by the U.S. Department of Energy (DOE) through the Office of Biological and Environmental Research (BER) Terrestrial Carbon Processes (TCP) program (Grants \# 10509-0152, DE-FG02-00ER53015, and DE-FG02-95ER62083), the United States-Israel Binational Agricultural Research and Development Fund (IS3861-06), by the National Science Foundation (NSFEAR 06-28342 and 06-35787) and through their Graduate Research Fellowship Program, and by the James B. Duke Fellowship program at Duke University.

\section{Appendix A}

To assess the sensitivity of $G_{\text {sref }}$ to $A_{S} / A_{L}, \Psi_{\text {leaf }}, k_{s}$, and $h$, consider a Taylor series expansion of $G_{\text {sref }}$ :

$\partial G_{\text {sref }}=\frac{\partial G_{\text {sref }}}{\partial A_{S} / A_{L}} \delta A_{S} / A_{L}+\frac{\partial G_{\text {sref }}}{\partial \Psi_{\text {leaf }}} \delta \Psi_{\text {leaf }}+\frac{\partial G_{\text {sref }}}{\partial k_{s}} \delta k_{s}+\frac{\partial G_{\text {sref }}}{\partial h} \delta h$.

Upon computing all the partial derivatives in Eq. (A.1) using Eq. (5) and expressing the outcome as relative changes, the above equation simplifies to

$\frac{\delta G_{\text {sref }}}{G_{\text {sref }}}=\frac{\delta A_{S} / A_{L}}{A_{S} / A_{L}}+\frac{\delta k_{s}}{k_{s}}+\frac{1}{1-\rho_{w} g h\left(\Psi_{\text {leaf }}\right)^{-1}}\left(\frac{\delta \Psi_{\text {leaf }}}{\Psi_{\text {leaf }}}-\frac{\delta h}{h}\right)$.

Eq. (A.2) analytically demonstrates that the relative change in $G_{s r e f}$ scales linearly with the relative changes in $A_{S} / A_{L}$ and $k_{S}$, but not with $\Psi_{\text {leaf }}$ and $h$. Using typical literature values as 'reference states' $\left(\Psi_{\text {leaf }}=-2 \mathrm{MPa}, k_{s}=3 \mathrm{~m}^{2}, h=20 \mathrm{~m}\right.$ and $\left.A_{S} / A_{L}=4 \mathrm{~cm}^{2} \mathrm{~m}^{-2}\right)$, Eq. (A.2) is evaluated for a range of values bounded by the extremes cited in the text. The results suggest that $G_{\text {sref }}$ varies by a factor of $\sim 10$ with $h$, by a factor of $\sim 3.5$ with $A_{S} / A_{L}$, and by a factor of $\sim 0.5$ with $\Psi_{\text {leaf }}$ and $k_{s}$. Stated differently, the sensitivity analysis in Eq. (A.2) demonstrates that when considering the reported variations in the literature in each of these parameters across species, $\delta k_{S} / k_{s} \ll \frac{\delta A_{S} / A_{L}}{A_{S} / A_{L}}$ and $\delta \Psi_{\text {leaf }} / \Psi_{\text {leaf }} \ll \delta h / h$, although this argument need not hold for all species.

Nevertheless, among many species a reasonable approximation is:

$G_{\text {sref }} \approx \frac{\delta A_{S} / A_{L}}{A_{S} / A_{L}}-\frac{1}{1-\rho_{w} g h\left(\Psi_{\text {leaf }}^{-1}\right)} \frac{\delta h}{h}$.

As expected, Eq. (A.3) analytically predicts that $G_{\text {sref }}$ diminishes rapidly with increasing height for small $h$ if no adjustments in $A_{S} / A_{L}$ occur.

\section{References}

[1] Granier A, Loustau D, Breda N. A generic model of forest canopy conductance dependent on climate soil water availability and leaf area index. Ann Forest Sci 2000;57(8):755-65.

[2] Oren R, Sperry J, Katul G, Pataki D, Ewers B, Philips N, et al. Survey and synthesis of intra- and interspecific variation in stomatal sensitivity to vapour pressure deficit. Plant Cell Environ 1999;22(12):1515-26.

[3] Jarvis PG. Interpretation of variations in leaf water potential and stomatal conductance found in canopies in the field. Philos Trans Roy Soc Lond Series BBiol Sci 1976;273(927):593-610.

[4] Schäfer KVR, Oren R, Tenhunen JD. The effect of tree height on crown level stomatal conductance. Plant Cell Environ 2000;23(4):365-75.
[5] Delzon S, Sartore M, Burlett R, Dewar R, Loustau D. Hydraulic responses to height growth in Maritime pine trees. Plant Cell Environ 2004;27(9):1077-87.

[6] Ryan MG, Phillips N, Bond BJ. The hydraulic limitation hypothesis revisited. Plant Cell Environ 2006;29(3):367-81.

[7] Kucharik CJ, Barford CC, El Maayar M, Wofsy SC, Monson RK, Baldocchi DD. A multiyear evaluation of a dynamic global vegetation model at three Ameriflux forest sites: vegetation structure phenology soil temperature and $\mathrm{CO}_{2}$ and $\mathrm{H}_{2} \mathrm{O}$ vapor exchange. Ecol Model 2006;196(1-2):1-31.

[8] Siqueira MB, Katul GG, Sampson DA, Stoy PC, Juang JY, McCarthy HR, et al. Multiscale model intercomparisons of $\mathrm{CO}_{2}$ and $\mathrm{H}_{2} \mathrm{O}$ exchange rates in a maturing Southeastern U.S. pine forest. Global Change Biol 2006;12(7):1189-207.

[9] Lefsky MA, Cohen WB, Acker SA, Parker GG, Spies TA, Harding D. Lidar remote sensing of the canopy structure and biophysical properties of Douglas-fir Western Hemlock forests. Remote Sens Environ 1999;70(3):339-61.

[10] Lefsky MA, Cohen WB, Parker GG, Harding DJ. Lidar remote sensing for ecosystem studies. Bioscience 2002;52(1):19-30.

[11] Kellndorfer J, Walker W, Pierce L, Dobson C, Fites JA, Hunsaker C, et al Vegetation height estimation from shuttle radar topography mission and national elevation datasets. Remote Sens Environ 2004;93(3): 339-58.

[12] Köstner B, Falge E, Tenhunen JD. Age-related effects on leaf area/sapwood area relationships canopy transpiration and carbon gain of Norway spruce stands (Picea abies) in the Fichtelgebirge, Germany. Tree Physiol 2002;22(8):567-74.

[13] Addington RN, Donovan LA, Mitchell RJ, Vose JM, Pecot SD, Jack SB, et al. Adjustments in hydraulic architecture of Pinus palustris maintain similar stomatal conductance in xeric and mesic habitats. Plant Cell Environ 2006;29(4):535-45.

[14] Ryan MG, Bond BJ, Law BE, Hubbard RM, Woodruff D, Cienciala E, et al. Transpiration and whole-tree conductance in ponderosa pine trees of different heights. Oecologia 2000;124(4):553-60.

[15] Lai CT, Katul G, Butnor J, Siqueira M, Ellsworth D, Maier C, et al. Modelling the limits on the response of net carbon exchange to fertilization in a SouthEastern Pine forest. Plant Cell Environ 2002;25(9):1095-119.

[16] Phillips N, Bond BJ, McDowell NG, Ryan MG, Schauer A. Leaf area compounds height-related hydraulic costs of water transport in Oregon White Oak trees. Funct Ecol 2003;17(6):832-40.

[17] Becker P, Meinzer FC, Wullschleger SD. Hydraulic limitation of tree height: a critique. Funct Ecol 2000;14(1):4-11.

[18] Mencuccini M, Bonosi L. Leaf/sapwood area ratios in Scots pine show acclimation across Europe. Canadian Journal of Forest Research-Revue Canadienne De Recherche Forestiere 2001;31(3):442-56.

[19] Barnard HR, Ryan MG. A test of the hydraulic limitation hypothesis in fastgrowing Eucalyptus saligna. Plant Cell Environ 2003;26(8):1235-45.

[20] Tyree MT. The cohesion-tension theory of sap ascent: current controversies. J Exp Bot 1997;48(315):1753-65.

[21] Whitehead D, Edwards WRN, Jarvis PG. Conducting sapwood area foliage area and permeability in mature trees of Picea sitchensis and Pinus contorta. Canadian Journal of Forest Research-Revue Canadienne De Recherche Forestiere 1984;14(6):940-7.

[22] Tyree MT, Ewers FW. The hydraulic architecture of trees and other woodyplants. New Phytol 1991;119(3):345-60.

[23] Whitehead D. Regulation of stomatal conductance and transpiration in forest canopies. Tree Physiol 1998;18(8-9):633-44.

[24] Ewers BE, Oren R, Sperry JS. Influence of nutrient versus water supply on hydraulic architecture and water balance in Pinus taeda. Plant Cell Environ 2000;23(10):1055-66.

[25] Koch GW, Sillett SC, Jennings GM, Davis SD. The limits to tree height. Nature 2004;428(6985):851-4.

[26] Meinzer FC. Functional convergence in plant responses to the environment. Oecologia 2003;134(1):1-11.

[27] Ewers BE, Gower ST, Bond-Lamberty B, Wang CK. Effects of stand age and tree species on canopy transpiration and average stomatal conductance of boreal forests. Plant Cell Environ 2005;28(5):660-78.

[28] Sobrado MA. Aspects of tissue water relations and seasonal-changes of leaf water potential components of evergreen and deciduous species coexisting in tropical dry forests. Oecologia 1986;68(3):413-6.

[29] Maherali H, Pockman WT, Jackson RB. Adaptive variation in the vulnerability of woody plants to xylem cavitation. Ecology 2004;85(8):2184-99 [Times Cited: 48].

[30] Oren R, Sperry JS, Ewers BE, Pataki DE, Phillips N, Megonigal JP. Sensitivity of mean canopy stomatal conductance to vapor pressure deficit in a flooded Taxodium distichum $\mathrm{L}$. forest: hydraulic and non-hydraulic effects. Oecologia 2001;126(1):21-9.

[31] McDowell N, Barnard H, Bond BJ, Hinckley T, Hubbard RM, Ishii H, et al. The relationship between tree height and leaf area: sapwood area ratio. Oecologia 2002;132(1):12-20.

[32] Magnani F, Mencuccini M, Grace J. Age-related decline in stand productivity: the role of structural acclimation under hydraulic constraints. Plant Cell Environ 2000;23(3):251-63.

[33] Sperry JS, Adler FR, Campbell GS, Comstock JP. Limitation of plant water use by rhizosphere and xylem conductance: results from a model. Plant Cell Environ 1998;21(4):347-59.

[34] Tyree MT, Sperry JS. Do woody-plants operate near the point of catastrophic xylem dysfunction caused by dynamic water-stress - answers from a model. Plant Physiol 1988;88(3):574-80. 
[35] Maherali H, Moura CF, Caldeira MC, Willson CJ, Jackson RB. Functional coordination between leaf gas exchange and vulnerability to xylem cavitation in temperate forest trees. Plant Cell Environ 2006;29(4):571-83.

[36] Montheith J, Unsworth M. Principles of Environmental Physics. London: Edward Arnold; 1990.

[37] Stoy PC, Katul GG, Siqueira MBS, Juang JY, Novick KA, McCarthy HR, et al. Separating the effects of climate and vegetation on evapotranspiration along a successional chronosequence in the Southeastern US. Global Change Bio 2006;12(11):2115-35.

[38] Campbell G, Norman J. An Introduction to Environmental Biophysics. New York: Springer; 1998.

[39] Phillips N, Bergh J, Oren R, Linder S. Effects of nutrition and soil water availability on water use in a norway spruce stand. Tree Physiol 2001;21(1213):851-60.

[40] Simonin K, Kolb TE, Montes-Helu M, Koch GW. Restoration thinning and influence of tree size and leaf area to sapwood area ratio on water relations of Pinus ponderosa. Tree Physiol 2006;26(4):493-503.

[41] Atwell BJ, Henery ML, Whitehead D. Sapwood development in Pinus radiata trees grown for three years at ambient and elevated carbon dioxide partial pressures. Tree Physiol 2003;23(1):13-21.

[42] Pataki DE, Huxman TE, Jordan DN, Zitzer SF, Coleman JS, Smith SD, et al. Water use of two Mojave desert shrubs under elevated $\mathrm{CO}_{2}$. Global Change Biol 2000;6(8):889-97.

[43] Pataki DE, Oren R, Katul G, Sigmon J. Canopy conductance of Pinus taeda, Liquidambar styraciflua and Quercus phellos under varying atmospheric and soil water conditions. Tree Physiol 1998;18(5):307-15.

[44] Herbst M, Roberts JM, Rosier PTW, Gowing DJ. Seasonal and interannual variability of canopy transpiration of a hedgerow in southern England. Tree Physiol 2007;27(3):321-33.

[45] Dennis JJ. Nonlinear least-squares. In: Jacobs D, editor. State of the art in numerical analysis. Academic Press; 1977. p. 269-312.

[46] Ryan MG, Yoder BJ. Hydraulic limits to tree height and tree growth. Bioscience 1997:47(4):235-42

[47] Phillips NG, Ryan MG, Bond BJ, McDowell NG, Hinckley TM, Cermak J. Reliance on stored water increases with tree size in three species in the Pacific Northwest. Tree Physiol 2003;23(4):237-45

[48] Thomas SC, Winner WE. Photosynthetic differences between saplings and adult trees: an integration of field results by meta-analysis. Tree Physiol 2002;22(2-3):117-27.

[49] Alsheimer M, Kostner B, Falge E, Tenhunen JD. Temporal and spatial variation in transpiration of Norway spruce stands within a forested catchment of the Fichtelgebirge Germany. Ann Sci Forest 1998;55(1-2):103-23.

[50] Phillips N, Oren R, Zimmermann R. Radial patterns of xylem sap flow in nondiffuse- and ring-porous tree species. Plant Cell Environ 1996;19(8):983-90.

[51] Pothier D, Margolis HA, Waring RH. Patterns of change of saturated sapwood permeability and sapwood conductance with stand development. Canadian Journal of Forest Research-Revue Canadienne De Recherche Forestiere 1989;19(4):432-9.

[52] McDowell NG, Phillips N, Lunch C, Bond BJ, Ryan MG. An investigation of hydraulic limitation and compensation in large old Douglas-fir trees. Tree Physiol 2002;22(11):763-74.

[53] Phillips N, Bond BJ, McDowell NG, Ryan MG. Canopy and hydraulic conductance in young, mature, and old Douglas-fir trees. Tree Physiol 2002;22(2-3):205-11

[54] Rust S, Roloff A. Reduced photosynthesis in Old Oak (Quercus robur): the impact of crown and hydraulic architecture. Tree Physiol 2002;22(8):597-601.

[55] DeLucia EH, Maherali H, Carey EV. Climate-driven changes in biomass allocation in pines. Global Change Biol 2000;6(5):587-93.

[56] Oren R, Schulze ED, Matyssek R, Zimmermann R. Estimating photosynthetic rate and annual carbon gain in conifers from specific leaf weight and leaf biomass. Oecologia 1986;70(2):187-93.

[57] Meinzer FC, Bond BJ, Warren JM, Woodruff DR. Does water transport scale universally with tree size? Funct Ecol 2005;19(4):558-65.

[58] Ward EJ, Oren R, Sigurdsson BD, Jarvis PG, Linder S. Fertilization effects on mean stomatal conductance are mediated through changes in the hydraulic attributes of mature Norway spruce trees. Tree Physiol 2008;28(4):579-96.

[59] Blanken PD, Black TA. The canopy conductance of a boreal aspen forest: Prince Albert National Park Canada. Hydrol Proc 2004;18(9):1561-78.
[60] Bartlett PA, McCaughey JH, Lafleur PM, Verseghy DL. Modelling evapotranspiration at three boreal forest stands using the class: tests of parameterizations for canopy conductance and soil evaporation. Int J Climatol $2003 ; 23(4): 427-51$.

[61] Cienciala E, Kucera J, Lindroth A, Cermak J, Grelle A, Halldin S. Canopy transpiration from a boreal forest in Sweden during a dry year. Agr Forest Meteorol 1997;86(3-4):157-67.

[62] Poyatos R, Martinez-Vilalta J, Cermak J, Ceulemans R, Granier A, Irvine J, et al. Plasticity in hydraulic architecture of Scots pine across Eurasia. Oecologia 2007;153(2):245-59.

[63] Kumagai T, Tateishi M, Shimizu T, Otsuki K. Transpiration and canopy conductance at two slope positions in a Japanese cedar forest watershed. Agr Forest Meteorol 2008;148(10):1444-55.

[64] Pataki DE, Oren R. Species differences in stomatal control of water loss at the canopy scale in a mature bottomland deciduous forest. Adv Water Res 2003;26(12):1267-78.

[65] Tang JW, Bolstad PV, Ewers BE, Desai AR, Davis KJ, Carey EV. Sap flux-upscaled canopy transpiration stomatal conductance and water use efficiency in an old growth forest in the Great Lakes region of the United States. J Geophys ResBiogeosci 111(G2).

[66] Herbst M, Rosier PTW, Morecroft MD, Gowing DJ. Comparative measurements of transpiration and canopy conductance in two mixed deciduous woodlands differing in structure and species composition. Tree Physiol 2008;28(6):959-70.

[67] Oren R, Pataki DE. Transpiration in response to variation in microclimate and soil moisture in Southeastern deciduous forests. Oecologia 2001;127(4):549-59.

[68] Granier A, Loustau D. Measuring and modeling the - transpiration of a Maritime pine canopy from sap-flow data. Agr Forest Meteorol 1994;71(12):61-81.

[69] Porte A, Loustau D. Variability of the photosynthetic characteristics of mature needles within the crown of a 25-year-old Pinus pinaster. Tree Physiol 1998;18(4):223-32.

[70] Maier CA, Clinton BD. Relationship between stem $\mathrm{CO}_{2}$ efflux stem sap velocity and xylem $\mathrm{CO}_{2}$ concentration in young Loblolly pine trees. Plant Cell Environ 2006;29(8):1471-83.

[71] Arneth A, Kelliher FM, McSeveny TM, Byers AN. Assessment of annual carbon exchange in a water-stressed Pinus radiata plantation: an analysis based on eddy covariance measurements and an integrated biophysical model. Global Change Biol 1999:5(5):531-45.

[72] Kim HS, Oren R, Hinckley TM. Actual and potential transpiration and carbon assimilation in an irrigated poplar plantation. Tree Physiol 2008;28(4):559-77.

[73] Coyea MR, Margolis HA. Factors affecting the relationship between sapwood area and leaf-area of Balsam fir. Canadian Journal of Forest Research-Revue Canadienne De Recherche Forestiere 1992;22(11):1684-93.

[74] Gilmore DW, Seymour RS, Maguire DA. Foliage-sapwood area relationships for Abies balsamea in central Maine USA. Canadian Journal of Forest ResearchRevue Canadienne De Recherche Forestiere 1996;26(12):2071-9.

[75] Sala A. Hydraulic compensation in northern Rocky Mountain conifers: does successional position and life history matter? Oecologia 2006;149(1):1-11.

[76] Mokany K, McMurtrie RE, Atwell BJ, Keith H. Interaction between sapwood and foliage area in Alpine Ash (Eucalyptus delegatensis) trees of different heights. Tree Physiol 2003;23(14):949-57.

[77] Tobin B, Black K, Osborne B, Reidy B, Bolger T, Nieuwenhuis M, et al. Assessment of allometric algorithms for estimating leaf biomass, leaf area index and litter fall in different-aged Sitka spruce forests. Forestry 2006;79(4):453-65.

[78] Monserud RA, Marshall JD. Allometric crown relations in three northern Idaho conifer species. Canian Journal of Forest Research-Revue Canadienne De Recherche Forestiere 1999;29(5):521-35.

[79] Monserud RA, Marshall JD. Time-series analysis of delta C-13 from tree rings I time trends and autocorrelation. Tree Physiol 2001;21(15): 1087-102.

[80] Martinez-Vilalta J, Vanderklein D, Mencuccini M. Tree height and age-related decline in growth in Scots pine (Pinus sylvestris L.). Oecologia 2007;150(4):529-44 